\title{
Characteristics of artisanal fisheries in the upper reaches of Bonny Estuary, Niger Delta, Nigeria
}

\begin{abstract}
Characteristics of artisanal fisheries in the upper reaches of Bonny Estuary were investigated for a period of six months from December 2014 to June 2015. Data were collected from randomly selected fishermen from five communities, viz., Bodo, Kpor, Bomu, Lewe and Gbe, using interview and open ended structured questionnaire. The research was carried out to ascertain the fish existed in the study area, types of gear, and methods of fishing, preservation and marketing techniques. The mean values of physico-chemical parameters such as temperature, dissolved oxygen (D.O), salinity, $\mathrm{pH}$, turbidity, and biological oxygen demand (BOD) were $30.47 \pm 1.34^{\circ} \mathrm{C}, 8.64 \pm 1.24 \mathrm{mg} / 1,16.4 \pm 5.78 \mathrm{ppt}, 7.66 \pm 0.76,117.0 \pm 16.9$ NTU and $4.94 \pm 2.66 \mathrm{mg} / 1$, respectively. A total of 52 fish species belonging to 24 families were identified and the species diversity and their abundance were determined. Tilapia guineensis was the highest in number (190) with $4.0 \%$ of abundance, while Sphryraena afra was the least in number (9) with $2.0 \%$ of abundance. The dry season (DecemberFebruary) recorded the number of 2,772 (57.7\%) fin fishes, while the wet season (AprilJune) found 2,028 (42.3\%). The mean number of fish caught was highest in station 2 and lowest in station 4 . The physico chemical parameters were within the acceptable limits for fish growth in brackish water ecosystem. The study revealed that the gear commonly used by the fishermen include cast nets, drag nets, hook and line, and traps, while the crafts used were mainly dug-out canoe and non-motorised boat. It also revealed that the constraints responsible for the low catch and poor standard of living of the fishermen as observed include high cost of gear materials, poor condition of boat, no access to credit facilities, destruction of nets by engine boat and environmental pollution. In view of the negative impacts that the aforementioned factors have on the fishermen, it is necessary to implement an effective management of the fisheries through proper enforcement and environmental laws and policies to safeguard and conserve the aquatic biota from going into extinction as well as restoring the source of livelihood to the fishermen in the area under investigation.
\end{abstract}

Volume 4 Issue 6 - 2019

\author{
Daniel Utibe I, Monsi BG \\ Department of Animal and Environmental Biology, University of \\ Port Harcourt, Nigeria
}

Correspondence: Daniel Utibe I, Department of Animal and Evironmental Biology, University of Port Harcourt, PMB 5323 Choba, East Road, Port Harcourt, Rivers State, Nigeria, Email utibe.danie@uniport.edu.ng

Received: October 22, 2019 | Published: November 15, 2019

Keywords: fish composition, upper reaches, bonny estuary, Nigeria

Abbreviations: DO, dissolved oxygen; BOD, biological oxygen demand; CPUE, catch per unit effort

\section{Introduction}

Fisheries play a very significant role in our national economy. ${ }^{1}$ A fishery is a term used to denote the exploitation, conservation, preservation, processing, marketing and consumption of fish and other aquatic organisms. A fishery is also concerned with the type of water body and depth, the fish species, stock assessment, the gear and craft used. Fishing gear can be described as any kind of equipment used in harvesting, cropping or capturing fish from any water body, ${ }^{2}$ while fishing method defines how the gear is used for catching fish.

Fisheries consists of coastal (industrial) and artisanal (traditional) fisheries. Industrial fisheries are capital intensive, carried out by companies, corporations or individuals with relatively large vessels fitted with inboard engines and mechanically operated gears. The vessels may be few and berth at only well-organized fishing ports with shore-based storage and processing facilities. The profitability of the exercise is usually reflected from the large gross landings per trip. ${ }^{3}$

Artisanal fisheries are small-scale fisheries for subsistence or local, small markets, generally using traditional fishing techniques and small boats. Productivity and income are generally low and infrastructural backing and credit are lacking. They occur around the world (particularly in developing nations) and are vital to livelihoods and food security. Comparatively, artisanal and commercial fisheries catch the same amount of fish for human consumption (30 million tons), yet artisanal fisheries employ 25 times the number of fishermen over (12 million people) and use eight times of the amount of fuel used by industrial fisheries annually.

In Nigeria, large populations of artisanal fishermen who rely on the predominant use of small fishing gear are found around the coastal communities. This group of fishermen commonly operate in inland rivers, Lagoons and nautical miles of the sea shore. ${ }^{4}$

Faturotu, (2010) reported that artisanal fisheries in Nigeria provide more than $82 \%$ of the domestic fish supply, giving livelihoods to 1 million fishermen and up to 5.8 million fisher folks in the secondary sector.

In the formulation of any fisheries developmental, management or conservation plan or models, it is important to know the fish species diversity, abundance and distribution in the study area as well as examining the factors influencing the structure of the fish community. Therefore, this research seeks to examine the physicochemical parameters of waters, species abundance and distribution as well as the gear and crafts used in the study area as a prelude to determining the fisheries stock, exploitation rate and catch per unit effort (CPUE), processing and marketing patterns that can be investigated in the subsequent studies. 


\section{Materials and methods}

\section{Description of the study area}

The study was carried out on the Kpador Bara and Dor Nwezor water system (Bodo creek) located at the upper reaches of Bony estuary (Figure 1). The creek lies between the Latitude $6^{\circ} 75,7^{\circ} 15 \mathrm{~N}$, and Longitudes $5^{\circ} 31 \mathrm{E}$ and $5^{\circ} 35 \mathrm{E}$ with an annual rainfall of 2000 $3000 \mathrm{~mm}$ in the Niger Delta. ${ }^{5}$ The rainy season spans from April to November (eight months), whereas the short dry season lasts for four months from December to March with occasional rainfall. ${ }^{6}$

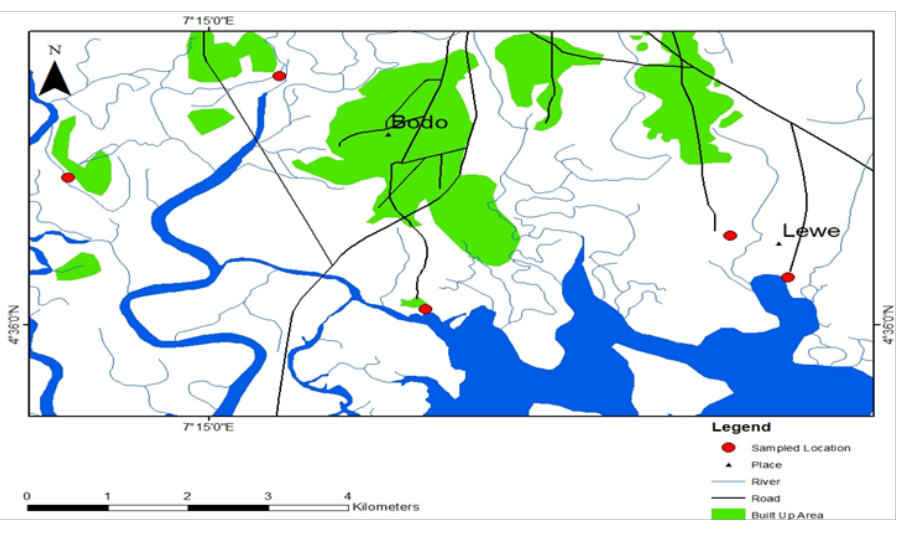

Figure I Map of Gokana indicating the sampling stations.

Bodo creek is a nexus of creeks with adjoining community on the upper reaches of the Andoni and Bonny river estuaries. ${ }^{5}$ Based on the pattern of hydrology, Bodo creek complex could be described as a "mixing sponge" for the waters from the Andoni and Bonny estuaries, where water flows swiftly unidirectional during the flowing and ebbing tide. The vegetation of the creeks is dominated by red mangroves (Rhizophora racemosa) and white mangroves (Avecennia africana), while other macrophytes are mangrove fern (Acrosticulum aureum) and nypa palm (Nypa fructicans). Presently, the study area is more prone to pollution as a result of illegal refining and exploitation activities. ${ }^{5}$ The flushing action of the tidal flows contributes to moving of these pollutants down into the study area.

\section{Experimental design}

A total of five sampling stations were randomly selected from five communities that makes up the upper reaches of the Bonny estuary namely: Station 1: Kozo $\left(04.60240^{\circ} \mathrm{N}, 007.27435^{\circ} \mathrm{E}\right)$, Station 2: Bon Kpor $\left(04.63803^{\circ} \mathrm{N}, 007.25794^{\circ} \mathrm{E}\right)$, Station 3 : Bo Koroma $\left(04.60738^{\circ} \mathrm{N}\right.$, $\left.007.31492^{\circ} \mathrm{E}\right)$, Station 4: Kibani $\left(04.61369^{\circ} \mathrm{N}, 007.30850^{\circ} \mathrm{E}\right.$ and Station 5: Bon Busime $\left(04.62252^{\circ} \mathrm{N}, 007.23420^{\circ} \mathrm{E}\right)$.

\section{Data collection}

Physico-chemical parameters of the study area: Water samples were collected in the morning hours between 8:00 and 10:00 h from five different sampling stations with five $200 \mathrm{ml}$ containing amber sample bottles corked in such a manner that any bubbles were not trapped They were then transported to the laboratory for further analysis. The time of sampling was dictated by two hydrological seasons; therefore two sets of samples were obtained: the first during the dry season (December-February) and the other during rainy season (April-June) of 2014 and 2015, respectively. The physical and chemical parameters evaluated were dissolved oxygen, temperature, salinity, $\mathrm{pH}$, turbidity and BOD. Some of the parameters were measured in situ, such as temperature, using mercury-in-glass Thermometer with the probe inserted into the water and the values were recorded as degree Celsius $\left({ }^{\circ} \mathrm{C}\right)$. Salinity was measured as parts per thousand (ppt) using a handheld Refractometer (Model New S-100). The turbidity was also measured in situ, using $30 \mathrm{~cm}$ diameter Secchi disc.

Fish samples: Fish samples were collected from the landings (homeports) of the artisanal and subsistence fishers. The samples was separated into dry and wet seasons, where the months of December, January and February were sampled for dry season and the months April, May and June were sampled for the wet season. Catches were counted and preserved in $10 \%$ formalin solution and taken to the laboratory for further analysis.

\section{Results}

\section{Physico-chemical parameters}

The monthly mean values of physico-chemical parameters or characteristics of the sampled rivers/estuaries between December 2014 and June 2015 are presented in Table 1. The measured water parameters include: temperature, dissolved oxygen, salinity, $\mathrm{pH}$, turbidity and biological oxygen demand. As presented, there seemed to be a regular pattern among the variables in such manners that as one is increasing in the wet season the other is decreasing in the dry season and vice versa.

Table I Mean values of physico-chemical parameters of the upper bonny estuary during December 2014 to June 2015 and their permissible limits

\begin{tabular}{lllllll}
\hline $\begin{array}{l}\text { Physico-chemical } \\
\text { parameters }\end{array}$ & Station I & Station 2 & Station 3 & Station 4 & Station 5 & $\begin{array}{l}\text { Permissible } \\
\text { limits }\end{array}$ \\
\hline Temperature (0C) & $30.47 \pm 0.05$ & $30.51 \pm 0.04$ & $30.74 \pm 0.01$ & $30.14 \pm 0.04$ & $30.47 \pm 0.04$ & $<230 \mathrm{c}-330 \mathrm{c}$ \\
Dissolved oxygen mg/l & $8.80 \pm 0.02$ & $8.70 \pm 0.03$ & $8.70 \pm 0.05$ & $8.63 \pm 0.02$ & $8.35 \pm 0.04$ & $0.5-8.6$ \\
Salinity ppt & $16.10 \pm 0.03$ & $16.80 \pm 0.02$ & $15.95 \pm 0.02$ & $16.70 \pm 0.05$ & $17.13 \pm 0.05$ & $<10-25$ \\
$\mathrm{pH}$ & $7.80 \pm 0.04$ & $7.80 \pm 0.01$ & $7.77 \pm 0.02$ & $7.68 \pm 0.03$ & $7.24 \pm 0.03$ & $6.5-9.5$ \\
Turbidity mg/l & $115.80 \pm 0.04$ & $116.1 \pm 0.05$ & $117.08 \pm 0.01$ & $116.02 \pm 0.01$ & $120.00 \pm 0.02$ & $<500$ \\
\hline
\end{tabular}

From the table, it can be deduced that the lowest water temperature $\left(27.25^{\circ} \mathrm{C}\right)$ occurred in June 2015 at station 4 and the highest temperature $\left(32.15^{\circ} \mathrm{C}\right)$.was recorded in December 2014 at station 1. Dissolved oxygen was observed to be highest $(10.45 \mathrm{mg})$ around June $2015 / 1$ in station 1 and lowest $(6.85 \mathrm{mg} / \mathrm{l})$ in station 5 around December 2014.
The water $\mathrm{pH}$ ranged between 6.5 and 8.8 across the stations. The mean $\mathrm{pH}$ value was lowest (6.5) in station 5 around December 2014 and recorded its highest value (8.8) in station 1 around June 2015.

Regarding the salinity of the water body, it recorded to its highest mean value (22.95ppt) at station 5 in December 2014. This parameter was the lowest (9.3ppt) in May 2015 as observed in station 1. 
The turbidity of the water body was found to be highest in December 2015, with a value of $135.75 \mathrm{mg} / 1$ in station 5 . The water turbidity ranged from 93.25 in June 2015 to $135.75 \mathrm{mg} / 1$ in December 2014. For the biological oxygen demand (BOD) of the water bodies, it showed a considerable variability in the observed values. It was ranged between $1.2 \mathrm{mg} / \mathrm{l}$ in December 2014 (station 1) to $8.15 \mathrm{mg} / \mathrm{l}$ in June 2015 (stations 1, 2 and 3).

\section{Monthly mean values of physico-chemical parameters}

The mean values of physico-chemical parameters of the upper reaches of bonny estuary are presented in Table 1. The highest temperature $30.74 \pm 0.01$ was recorded in station 3 and the lowest $(30.14 \pm 0.04)$ was recorded in station 4 .

Dissolved oxygen was highest $(8.80 \pm 0.02 \mathrm{mg} / \mathrm{l})$ in sample station 1 and lowest $(8.35 \pm 0.04)$ in sample station 2 . With a mean value of $8.7 \pm 0.03$. Biological oxygen demand ranged from $4.86 \pm 0.04$ to $4.99 \pm 0.05 \mathrm{mg} / 1$ with the highest $(4.99 \pm 0.05 \mathrm{mg} / 1)$ in sample station 3 and the lowest in sample at station 5. Stations 1 and 2 have the same mean values of BOD $(4.95 \pm 0.01 \mathrm{mg} / 1)$.

The salinity was ranged from $15.95 \pm 0.02$ to $17.13 \pm 0.05 \mathrm{ppt}$ and the lowest mean value $(17.13 \pm 0.02 \mathrm{ppt})$ was observed in sample station 5 , while the lowest value $(15.95 \pm 0.02)$ was in sample station 3 . The turbidity values were ranged from $115.80 \pm 0.04$ to $120.00 \pm 0.02 \mathrm{mg} / \mathrm{l}$ with the lowest value $(115.80 \pm 0.04)$ was in sample station 1 and the highest $(120.00 \pm 0.02)$ in station 5 .

\section{Distribution and abundance of fish}

The distribution and abundance of fish species per station are indicated in Table 2. A total of 52 fish species belonging to 24 families were identified in the various sampling stations. The most abundance of these families includes Carangidae, Clupeidae, Cichlidae, Scieanidae, Lutjanidae, Mugilidae, Pomadasidae and Gobiidae. The species that recorded to be the highest was Tilapia guinensis with a total number of 190 , accounting for a percentage of $4.0 \%$ of the total amount while the least species was Sphyraena afra with a number of 9 , which was no more than $0.2 \%$.

Table 2 Monthly variations of fish caught during December 2014 to June 2015

\begin{tabular}{lll}
\hline Month & $\begin{array}{l}\text { Total number of } \\
\text { fishes }(\mathbf{n})\end{array}$ & $\begin{array}{l}\text { Percentage number } \\
\text { of fishes (\%) }\end{array}$ \\
\hline December & 880 & 18.3 \\
January & 940 & 19.6 \\
February & 952 & 19.8 \\
April & 610 & 12.7 \\
May & 680 & 14.2 \\
June & 738 & 15.3 \\
Total & 4800 & 100 \\
\hline
\end{tabular}

The total number of fishes and their percentages are presented in Table 2. The numbers of fishes were ranged from 610 to 952 . A total number of fishes caught was $880(18.3 \%)$ in December, followed by $940(19.6 \%)$ in January, and the highest number of $952(19.8 \%)$ in February. In April, the number was 610 accounting for $12.7 \%$. May and June recorded a total number of $680(14.2 \%)$ and $738(15.3 \%)$, respectively, making a ground total of 4800 number of fishes caught during the study period.

\section{Seasonality and distribution of fish}

In total, $2,772(57.7 \%)$ fish was caught in the dry season, while $2,028(42.3 \%)$ was caught in the wet season. The species with the highest catch in both seasons was Tilapia guinensis. While Cynoglossus monody and Spyraena afra were the least abundant in the dry season, the Spyraena afra was the least in the wet season. Among the stations, sample station 1 had the highest catch of 1276 $(26.6 \%)$ during the study period, others were station $2(1,058)$ which was $22.0 \%$, station 3 had 897 (18.7\%), station 5 recorded $820(17.1 \%)$ and station 4 recorded 747 (15.6\%), which was the least number and proportions in the study. There was variability in terms of species and number caught per station. Ephippion guttifer was caught only in the dry season and Dasyatis margarita was caught in the rainy season.

\section{Discussions}

\section{Physico-chemical parameters in the study area}

The surface temperature ranged from $27.0^{\circ} \mathrm{C}$ to $322^{\circ} \mathrm{C}$. The maximum temperature $\left(32.2^{\circ} \mathrm{C}\right)$ was recorded in the month of January, 2015 and the minimum $\left(27.0^{\circ} \mathrm{C}\right)$ in June, 2015. The seasonal temperature recorded during the period of study shows that the temperature was high in the month of January and begins to fall from April through June, 2015. This may be as a result of high ambient temperature for fish during dry season (January) and low ambient temperature during the raining season (June). This completely agrees with the report of Francis (2003) in the Andoni River and slightly agrees with Onwugbuta-Enyi et al. ${ }^{5}$ Also runoff during raining season from inland could also be responsible for the fall in temperature of the study area from December, 2014 through June, 2015. However, the temperature range was within acceptable limits $\left(23^{\circ} \mathrm{C}-33^{\circ} \mathrm{C}\right)$ for warm water fish production (WHO, 2006; FEPA, 1996).

The values of dissolved oxygen (DO) were ranged from $6.9 \mathrm{mg} / 1$ in December, 2014 to $10.5 \mathrm{mg} / \mathrm{l}$ in June, 2015. The highest dissolved oxygen value was recorded in June, while the lowest value was recorded in December. During dry season (December, 2014-March, 2015), the dissolved oxygen was evaporated to the atmosphere from the surface water due to its sensitivity to high temperature.

However, during April-June, 2015, the dissolved oxygen increased as a result of dissolved atmospheric oxygen from rain water and high wind current. The high DO observed in the rainy season agrees with the findings of Yakubu et al. ${ }^{6}$ It also agrees with the report of Francis (2003) in the Andoni river system. The dissolved oxygen of the study area did not exceed minimum limits implying that such water can support fish growth and metabolism (FEPA, 1996). The relatively lower salinity levels during the rainy season and higher in the dry season were attributed to the dilution effect of increased river inflow through rain waters as reported by other researchers. ${ }^{7,8}$ In the study area, salinity appears to be influenced naturally by fresh water inflow, tidal stage and rainfall. The salinity range recorded during this study (9.1-23.0ppt) differed slightly from those of Ansa et al., (2007), who reported a range of 8.0-21.0ppt. However, our result agrees slightly with that of Francis et al., (2007) who reported a range of 2.2-9.2ppt.

The $\mathrm{pH}$ ranged from 6.5 to 9.3 across the sampling stations. The maximum $\mathrm{pH}$ value (9.3) was recorded in the month of June and minimum (6.5) in the month of December. Moyle (1993) reported that $\mathrm{pH}$ range of 5.5-10 will support aquatic growth adequately. The $\mathrm{pH}$ values of 6.5-9.3 recorded in the study area agrees with the $\mathrm{pH}$ of brackish water bodies reported by Imevbore (1971). The $\mathrm{pH}$ values fall within the optimum range of most aquatic organisms and will 
support rich primary productivity. The maximum value of $\mathrm{pH}$ was recorded in the month of June. This may be due to the presence of suspended particulate matter, influx of fresh water from the canal and rainfall. Upwelling is also a factor to be considered. ${ }^{5}$ The BOD levels were above the regulatory international standard for water quality. ${ }^{9}$

\section{Fish composition in the study area}

A total of 52 fish species belonging to 24 families were recorded in the upper reaches of bonny estuary during the study period. The fish composition recorded in the study compares favourably with those of brackish water systems in the lower Niger Delta region. It also agrees with the 25 families recorded in the lower Bonny River in the Niger Delta Nigeria. ${ }^{10}$ The species distribution was found to be determined by the nature of the water system among other factors (Nwadiaro, 1989). The species identified in the present study was high when compared to other studies in the Niger Delta. Sikoki et al, (1998) reported 24 species and 15 families in lower Nun River and Allison et al, (1997) 37 species and 22 families in Elechi Creek. In addition, Sikoki et al, (1999) found 22 species and 11 families of the brackish zone of the Brass River and Abowei $^{3}$ recorded 36 species and 22 families in the Lower Nun River. The variations in the number of finfish species could be attributed to differences in the physcio-chemical parameters. Francis and Sikoki (2003), working in Andoni river system, recorded 63 species from 48 genera belonging to 36 families. The observable differences between the fish composition of the study area and the nearby Andoni River system could be attributed to the sampling method and season. The relatively more abundance of the families Carangidae, Clupeidae, Cichlidae, Scieanidae, Lutjanidae, Mugilidae Pomadasidae and Gobiidae agrees with Sikoki and Francis (2007), who referred to the species as marine migrants that are bound in estuaries for the purpose of feeding and shelter before returning to the sea for breeding. Moses ${ }^{11}$ also reported that estuaries are highly productive zones which benefit fisheries by providing nursery grounds and also open large feeding grounds to adult fishes at high tide. This assertion might account for the numerous species recorded proving that the sampling areas may have served as a nursery ground. This is in agreement with Little et al., (1987) who noted creek serves as a nursery ground, in which fingerlings are developed.

In the study, dry season (December-February) recorded higher number $(2,772(57.7 \%)$ of finfish, while the wet season (April-June) had $2,028(42.3 \%)$. The seasonal variation of finfish population was higher in dry months than in the wet season months, is consistent with the report of Chindah and Osuamkpe..$^{10}$ Nevertheless, this report is contrary to the observation of Abowei, ${ }^{3}$ who found the higher wet season catch than dry season one, which was attributed to the dual occupation of the fishermen, crop in the dry season and fishing in the wet season.

A total of 87 gear types were identified during the study, viz., station 1 (10), station 2 (10), station 3 (6), station 4 (6), station 5 (5). It is the highest in station 1 and 2, which may be due to the number of fishermen in the area. The gear types recorded in the study were also observed in Bayelsa state by NIFFR, when she surveyed all the Inland water bodies in Nigeria for fishing gear and crafts. These were the commonest gear also in Lake Alau. ${ }^{12,13}$

The challenge encountered by the fishermen in the area agrees with the findings of Davies and Kwen. ${ }^{14}$ However, oil pollution was their major challenge and these are similar to the challenges encountered by artisanal fishermen in most parts of the Niger Delta in particular and Nigeria at large.

\section{Conclusion}

The results of this study have shown that the upper reaches of Bonny estuary like most other brackish water bodies in the Niger Delta region has a great potential for fisheries exploitation and is capable of providing the fishermen a source of sustainable livelihood if properly harnessed and managed.

\section{Acknowledgments}

We wish to acknowledge Prof. Abowei, Prof. F.D.Sikoki and Prof.A.I. Hart for their materials and publications which were used for our Literature review in this article. We also acknowledge Mr. Maxwell for the typesetting of the manuscript.

\section{Funding}

The funding for the research was absolutely self sponsored without any support from anywhere.

\section{Conflicts of interest}

The authors declared that there no conflicts of interest.

\section{References}

1. Sikoki F, Otobotekere AJT. Fisheries. In: Alagoa EC, editor. The land people of Bayelsa State Central Niger Delta. Port Harcourt; 1999:301319.

2. Nuhu MB, Yaro I. Selection of efficient hanging ratios of gill net on fish catch in Lake Kainji, as a means of alleviating poverty among artisanal fishermen in Nigeria. In: Araoye PA, editor. Proceedings of the 19 Annual Conference of the Fisheries Society of Nigeria (FISON). 2005:64-72.

3. Abowei JEN. Aspects of the fisheries of the lower Nun river, Nigeria. PhD thesis, Nigeria: University of Port Harcourt; 2000. 248 p.

4. Adesulu EA, Sydenham DHJ. The freshwater fishes and fisheries of Nigeria. Lagos: Macmillan Nigeria Publishers; 2002. 397 p.

5. Onwugbuta-Enyi J, Zabbey N, Erondu ES. Water quality of Bodo Creek in Lower Niger Delta Basin. Advances in Environmental Biology. 2008;2(3):132-136.

6. Yakubu AF, Sikoki FD, Horsfall JRM. Investigation into the physciochemical conditions and planktonic organisms of the lower researches of the Nun River, Nigeria. Journal of Applied Sc and Env Management. 1998;1(1):41.

7. Edokpayi CA. Variation of chemical constituents of a brackish water prawn habitat in Southern Nigeria. actaSATACH. 2005;2(1):11-18.

8. Abowei JFN. Salinity, dissolved oxygen, $\mathrm{pH}$ and surface water temperature conditions in Nkoro Rivers, Niger Delta, Nigeria. Adv J of food Sci and Tech. 2010;2(1):36-40.

9. Anyanwu IN. Aspects of fish fauna (Ichthyofauna) and physico-chemical properties of Onu-Iyi-Ukwu River. MSc Thesis, University of Port Harcourt; 2004.

10. Chindah AC, Osuamkpe A. The fish assemblage of the lower bonny rivers, Niger Delta, Nigeria. African Journal Ecology. 1994;32(1):58-65.

11. Moses BS. Artisanal fisheries of south eastern Nigeria, catch rates, population dynamics, potential yield and resource management. $\mathrm{PhD}$ thesis, Uyo, Nigeria: University of Uyo; 1997. 205 p. 
12. Bankole NO, Raji A, Adikwu IA, et al. Fishing gear survey of Lake Alau. In: Eyo AA, Ajao EA, editors. Proceedings of the $16^{\text {th }}$ annual conference of the fisheries society of Nigeria (FISCON). 2003:99-103.

13. Yisa ZF, Apeloko A, Kasali. Fishing gear survey, Kainiji Lake. NIFFR Annual Report. 1995:212-215.
14. Davies OA, Kwen K. Status and constraints of artisanal fishers in the lower Taylor Creek Area, Niger Delta, Nigeria. Journal of Aquatic Sciences. $2013 ; 28(1): 1-8$ 